九州大学学術情報リポジトリ

Kyushu University Institutional Repository

\title{
The Demand for Chemical Fertilizers in China
}

Peng, Daiyan

Department of Agricultural Economics, Graduate School of Bioresource and Bioenvironmental Sciences, Kyushu University

Kawaguchi, Tsunemasa

Laboratory of Quantitative Analysis of Agribusiness Organization, Division of Industrial Organization of Agribusiness, Department of Agricultural and Resource Economics, Faculty of Agriculture, Kyushu University

https://doi.org/10.5109/24415

出版情報: 九州大学大学院農学研究院紀要. 45 (2)，pp.651-666，2001-02-28. Kyushu University バージョン：

権利関係 : 


\title{
The Demand for Chemical Fertilizers in China
}

\author{
Daiyan Peng* and Tsunemasa Kawaguchi \\ Laboratory of Quantitative Analysis of Agribusiness Organization, Division of Industrial \\ Organization of Agribusiness, Department of Agricultural and Resource Economics, \\ Faculty of Agriculture, Kyushu University, Fukuoka 812-8581 \\ (Received October 31, 2000 and accepted November 10, 2000)
}

\begin{abstract}
During the past two decades, the tremendous increase in the use of chemical fertilizers compared with other inputs in Chinese agriculture is particularly impressive. This growing use of chemical fertilizers has played a crucial role in Chinese agricultural growth. In the future, the use of chemical fertilizers will continue to play an unsubstitutably important role. As land become more scarce, the future growth of Chinese agriculture will mainly depend on technological progress like the adoption of new seed varieties. While the new technologies' effect can only be realized in combination with the use of chemical fertilizers usually. However, the increasing use of chemical fertilizers may cause serious environment problems, such an example is the intrate problem. Thus how to keep agriculture grow continuously to feed her still growing population without deteriorating the fragile environment, hence, how to use chemical fertilizers rationally and efficiently, becomes an urgent theme. The objectives of this paper are to estimate the demand function and account for the growth of chemical fertilizers in China.

The main results are as follows. Similar to what have been made clear in other countries by previous studies, the demand for chemical fertilizers in China is affected by its own price negatively and agricultural price positively. Technological progress is a strong force of inducing the use of chemical fertilizers. The adoption of Household Responsibility System improves the use of chemical fertilizers during the institutional reform period. Disaster also has a negative effect. The arguement that labor is a substitute for CFs could not have been empirically verified.

Keywords: chemical fertilizers, demand function, chemical fertilizer price, agricultural price, Household Responsibility System, disaster, technological progress, substitute, growth rate.
\end{abstract}

\section{INTRODUCTION}

The tremendous increase in the use of chemical fertilizers (CFs) compared with other inputs in Chinese agriculture during the past two decades is particularly impressive. As shown in Table 1, during the period 1978-97, though irrigated land area increased $13.86 \%$, cultivated land area decreased $11.24 \%$. Agricultural labor force grew $10.23 \%$. During this period, farm machinery increased 2.57 times, but if we took it into consideration that a large proportion of farm machinery was used for non-agricultural purposes such as transportation (Zhang and Carter, 1997) and it grows as rural economies develop, the growing speed of machinery used in agriculture would be dramatically lowered. Compared with these inputs, it is noticeable that the use of CFs grew 3.5 times. This growing use of CFs has played a crucial role in Chinese agricultural

\footnotetext{
* Department of Agricultural Economics, Graduate School of Bioresource and Bioenvironmental Sciences, Kyushu University, Corresponding author.
} 
Table 1. Index of Inputs $(1978=100)$

\begin{tabular}{cccccc}
\hline & $\begin{array}{c}\text { Cultivated } \\
\text { land area }\end{array}$ & $\begin{array}{c}\text { Irrigated } \\
\text { land area }\end{array}$ & $\begin{array}{c}\text { Agricultural } \\
\text { labor force }\end{array}$ & $\begin{array}{c}\text { Farm } \\
\text { machinery }\end{array}$ & $\begin{array}{c}\text { Chemical } \\
\text { fertilizers }\end{array}$ \\
\hline 1978 & $(1)$ & $(2)$ & $(3)$ & $(4)$ & $(5)$ \\
\hline 1979 & 100.00 & 100.00 & 100.00 & 100.00 & 100.00 \\
1980 & 93.46 & 102.22 & 100.00 & 113.87 & 122.85 \\
1981 & 92.52 & 104.44 & 102.67 & 125.50 & 143.55 \\
1982 & 92.52 & 100.00 & 105.93 & 133.45 & 151.02 \\
1983 & 92.52 & 100.00 & 108.79 & 141.40 & 171.15 \\
1984 & 91.92 & 100.00 & 107.54 & 153.38 & 187.78 \\
1985 & 91.45 & 100.00 & 107.68 & 169.51 & 196.83 \\
1986 & 90.51 & 100.00 & 103.15 & 181.82 & 200.90 \\
1987 & 89.93 & 100.00 & 103.54 & 199.53 & 218.44 \\
1988 & 89.62 & 100.00 & 104.91 & 215.92 & 226.13 \\
1989 & 89.46 & 100.00 & 106.90 & 231.03 & 242.31 \\
1990 & 89.40 & 100.00 & 110.24 & 238.72 & 266.63 \\
1991 & 89.41 & 105.34 & 113.29 & 244.16 & 293.02 \\
1992 & 89.40 & 106.27 & 116.18 & 249.95 & 317.32 \\
1993 & 89.18 & 107.98 & 115.67 & 257.78 & 331.47 \\
1994 & 88.88 & 108.28 & 113.02 & 270.60 & 356.55 \\
1995 & 88.70 & 108.35 & 11.09 & 287.49 & 375.33 \\
1996 & 88.76 & 109.51 & 109.88 & 307.19 & 406.53 \\
1997 & 89.22 & 11.96 & 109.63 & 327.85 & 433.02 \\
\hline & 88.76 & 113.86 & 110.23 & 357.35 & 450.31 \\
\hline
\end{tabular}

Note: Chemical fertilizers are the quantities of the "principal plant nutrients" of all fertilizers.

Source: Cultivated land area: Wen (1993, pp. 8-9, Table 2) for 1978-89, China Statistical Yearbook (CSY, 1998, p. 389) for 1990-95, China Agricultural Yearbook (CAY, 1997, p. 287) for 1996, CSY (1998, p. 5) for 1997; irrigated land area: Wen (1993, pp. 8-9, Table 2) for 1978-89, CSY (1998, p. 393) for 1990-97; agricultural labor forces: CSY (1984, p. 109) for 1978-82, CSY (1994, p. 328) for 1983-93; CSY (1998, p. 388) for 1994-97; Farm machinery: Wen (1993, pp. 12-3, Table 3) for 1978-89, CSY (1998, p. 391) for 1990-97. The original data were in kilowatts, and were converted into horsepower to keep consistency with the unit used by Wen (1993) (1 HP=0.736 KW); Chemical fertilizers: Wen (1993, pp. 16-7, Table 5) for 1978-89, CSY (1998, p. 393) for 1990-97.

growth. According to Lin (1992), among the conventional inputs, the contribution of CFs to the growth in crop output is the biggest, followed by capital during the period 1978-1987. Huang and Rozelle (1995)'s study also indicates that the use of CFs per ha of crop sown area contributed to $45.3 \%$ of the growth of grain yield between 1975 and 1990 , followed by labor per ha of crop sown area with only $6.9 \%$.

In the future, the increase in the use of CFs will continue to play an unsubstitutably important role in Chinese agricultural growth. As land becomes more scarce, the future growth of Chinese agriculture will mainly depend on technological progress like the adoption of new seed varieties. While the new technologies' effect can only be realized in combination with the use of CFs usually.

However, the increasing use of CFs may cause serious environment problems, such an example is the intrate problem. That the use of CFs, especially nitrogen and phosphorus, in agriculture causes the contamination of water has been recognized in the 
U.S. and the European Community (Larson and Vroomen, 1991). Researchers (e.g. Yao and Liu, 1998, p. 172, Note 2) have also begun to recognize this problem in China. How to keep agriculture grow continuously to feed her still growing population without deteriorating the fragile environment, hence how to use CFs rationally and efficiently, becomes an urgent theme. This paper mainly deals with the demand for CFs in China.

The demand for CFs has been a long concern of researchers and an abundant literature has been accumulated. But research on China seems lacking. The main objectives of the present study are to estimate the demand function of CFs in China by using time-series data between 1978 and 1997, and to explore the sources of CFs' growth since the rural economic reform.

The contents are organized as follows. Section 2 outlines the economic reforms in Chinese agriculture. Previous functional form specifications of the demand function of CFs are surveyed in Section 3. Section 4 provides a model framework of comparative statistic study. Empirical studies are carried out in Section 5. Accounting for CFs' growth since the rural economic reform is carried out in Section 6. Finally, some concluding remarks are presented in Section 7.

\section{ECONOMIC REFORMS IN CHINESE AGRICULTURE}

Much has been written on the market-oriented reforms in rural China beginning at the end of 1978 (Lin, 1992; Cheng, 1998). Because these reforms have shaped the background of the demand for CFs, in this section, I outline the most important aspects concerning the demand for CFs to provide a background for the theoretical and empirical studies in subsequent sections.

\section{1) Institutional Reform}

The most important reform in rural China is the abolition of the more than 20 years' being existed People's Commune System and the adoption of the Household Responsibility System (HRS). This reform began in 1979 and was essentially completed by the end of 1984. The institutional reform has transformed the basic agricultural production unit from production team to rural household. Under HRS, collectively owned land was assigned to individual households with contract of up to 15 years in 1984, being extended to 30 years in 1993, and then to 50 years in some districts recently. The households are obligated to pay government procurement quotas which are usually regarded as agricultural taxes and town and village public welfare expenses. After fulfilling these duties, the households are allowed to dispose the rest agricultural products freely.

\section{2) Agricultural Product Planning Reform}

In 1953, following the former Soviet Union, China adopted an agricultural product system called the "unified procurement and sales" (tonggou tongxiao) system. This system had characterized Chinese agricultural economy until 1984. Under the "unified procurement and sales" (tonggou tongxiao) and designated procurement program (paigou), national procurement quotas and prices of important agricultural products concerning national welfare were decided at the central government level, and both quota procurement purchase price and above-quota purchase price were used. The 
above-quota purchase price had been used to encourage farmers to offer more agricultural products to meet the needs of non-agricultural sectors.

In 1985, all mandatory production plans and obligatory procurement quotas in agriculture were replaced by procurement contracts, which were supposed to be negotiated between state-owned enterprises and farmers. The contract price was a weighted average of the basic quota price and the above-quota price (Lin, 1992, p. 36). After fulfilling the contract quotas, farmers are allowed to sell the surplus agricultural products freely in free markets. If the market price falls below the administrative protection price, the state-owned enterprises are obligated to buy all the agricultural products the farmers are willing to sell.

But there were some changes in the case of grains later. Because grain production declined significantly during $1985-88$, the voluntary procurement contract of grains was made mandatory again in fact to secure the needed grains. In 1988, the monopolistic management of the state-owned enterprises for grains was recovered. In 1990, procurement contract quotas were changed to ordered procurement quotas and farmers are obligated to complete them. The planning control has since been strengthened. Since 1998, any firm or individual has been forbidden from buying grains from farmers directly without prior permission (Cheng, 1998).

During the period 1978-97, agricultural price had been raised periodically in 1979, 1987, 1988, 1989, 1992, 1994, and 1996.

\section{3) Input Market Reform}

Generally speaking, the price of CFs has been strictly controlled by the governments. Before 1984, both the supply and the price of CFs were controlled administratively (Ye and Rozelle, 1994), though the price was lowered in the period 1980-81, and then raised in the period 1983-84. In 1985, the dual-track supply system of CFs was adopted. Under this system, the supply of CFs is divided into two parts. One part is adjusted administratively and its price is decided officially. The rest is adjusted by market. In 1987, a new policy called linking fulfilling procurement quotas with the supply of low price CFs, agricultural diesel oil, and vinyl was carried out, i.e. the farmers will be supplied with an amount of CFs, agricultural diesel oil, and vinyl at price lower than the market price when fulfilling procurement quotas. But the quantities were limited. Because the price of market-adjusted CFs was more than twice higher than that of administratively controlled CFs, administrative control of market-adjusted CFs was recovered, and the wholesale price management of CFs was implemented again in 1988. Furthermore, monopolistic management of CFs, agricultural diesel oil, and vinyl started in 1989. These important agricultural inputs can only be sought by China Corporation of Agricultural Means of Production and Rural Supply and Demand Co-operatives. The maximum price limitation and floating price system were adapted in 1993 and 1994 respectively. Under the floating price system, the price of CFs can only float between the controlled maximum and minimum prices (Cheng, 1998).

It is well-known that land market has not been formed yet. Agricultural land is owned by Rural Collective Organizations and prohibited from being sold or bought for agricultural purposes. Labor market has not been formed in most of Chinese countryside 
either.

\section{A SURVEY OF PREVIOUS FUNCTIONAL FORM SPECIFICATIONS}

Two recent surveys of the main approaches previously used to estimate the demand function of CFs have been provided by Burrell (1989) and Larson and Vroomen (1991) respectively. As Larson and Vroomen (1991) have pointed out, the functional forms previously used can be roughly classified into two broad types: (1) single-equation empirical specifications that are interpreted as reduced-form equations from some implicit theoretical model (e.g. Griliches, 1958; Hayami, 1964; Hayami and Ruttan, 1985; Heady and Yeh, 1959; Lingard, 1971; Metcal and Cowling, 1967; etc.) and (2) equation system empirical specifications explicitly derived from dual cost or profit functions (e.g. Boyle, 1982).

The advantages of the latter type of approaches are obvious: because the demand functions are based on widely accepted function forms, the estimated parameters are comparable among various studies. But this type of approach also involves serious problems. Though data on actual output are not known at the time of the use of CFs, the actual output data are used in the cost function approaches. Thus simultaneity between inputs and outputs is an issue. On the other hand, given the dynamic and the sequential nature of agricultural production process, an neoclassical profit function based on an instantaneous adjustment process may not adequately reflect the agricultural production process (Larson and Vroomen, 1991, p. 356; Burrell, 1989, p. 6). When the approach of equation system specifications derived from profit or cost functions has lost its basic theoretical foundations, the estimated results are hard to evaluate.

To avoid the fundamental theoretical deficiencies of the approach of equation system specifications, I employ the single-equation models in the present study, though this approach has also been criticized to have the following disadvantages: 'lack of theoretical restrictions apart from a priori expectations about the sign of coefficients; the use of $R^{2}$ as a measure of model validity; and model-specific estimated elasticities which can not be compared meaningfully with estimates from other models' (Larson and Vroomen, 1991).

\section{MODEL FRAMEWORK}

The demand for CFs is derived from the demand for agricultural products. Therefore the demand function for CFs can only be derived from the farmers' profit maximizing behavior.

Under HRS, farmers can be thought to maximize agricultural profit after fulfilling government procurement quotas ${ }^{1}$. The expected profit function of representative agricultural farm at the time of using CFs can be written as follows ${ }^{2}$.

$$
\text { EPROFIT }=E P R I C E\left[f\left(x_{1}, \ldots, x_{i}, \ldots, x_{k}, Z_{1}, \ldots, Z_{j}, \ldots, Z_{i} ; D, H\right)-Q_{g}\right]+P_{g} Q_{g}-\sum_{i=1}^{k} w_{i} x_{i}-K_{0}
$$

Where EPROFIT is the farm's expected profit, EPRICE is the expected price of agricultural products above government procurement quotas, $f\left(x_{1}, \ldots, x_{i}, \ldots, x_{k}, Z_{1}, \ldots, Z_{j}, \ldots\right.$, $\left.Z_{i} ; D, H\right)$ is the production function, which is assumed to meet the usual assumptions. $Q_{g}$ is the amount of government procurement quotas. $P_{g}$ is the price of government 
procurement quotas. $x_{i}$ 's $(\mathrm{i}=1,2, \ldots \mathrm{k})$ are the ith variable input, $w_{i}^{\prime} \mathrm{s}(\mathrm{i}=1,2, \ldots \mathrm{k})$ are the prices of the ith variable input, $Z_{j}$ 's $(j=1,2, \ldots 1)$ are the $j$ 'th fixed capital, and $K_{0}$ is the total fixed cost of production. $D$ is natural disaster ${ }^{3)}$. $H$ is the ratio of agricultural production teams fulfilling HRS to the whole teams, representing the productive effect of HRS.

As introduced above, government procurement quotas must be finished. After finishing government procurement quotas, farmers also sell agricultural products directly to non-agricultural residents through free markets (Du, 1995, p. 86), hence we can consider

$$
f\left(x_{1}, \ldots, x_{i}, \ldots, x_{k}, Z_{1}, \ldots, Z_{j}, \ldots, Z_{i} ; D, H\right)>Q_{g}
$$

Under this condition, the first-order conditions of profit maximization are

$$
\begin{array}{r}
E P R I C E \partial f\left(x_{1}, \ldots, x_{i}, \ldots, x_{k}, Z_{1}, \ldots, Z_{j}, \ldots, Z_{i} ; D, H\right) / \partial x_{i}=w_{i} \\
i=1,2, \ldots, \mathrm{k}
\end{array}
$$

The second-order conditions of profit maximization are assumed to be satisfied as well as assuming that production function meets the usual assumptions. Therefore, the input demand functions can be derived from Eqs. (2) according to the implicit function theorem.

$$
\begin{aligned}
& x_{i}=x_{i}\left(E P R I C E, w_{1}, \ldots, w_{i}, \ldots, w_{k}, Z_{1}, \ldots, Z_{j}, \ldots, Z_{i} ; D, H, T E C\right) \\
& \mathrm{i}=1,2, \ldots, \mathrm{k}
\end{aligned}
$$

These are a set of Marshallian input demand functions. $Z_{j}$ 's $(j=1, \ldots, 1)$ are included in the demand functions because they may be substitute or complement inputs for the considered input, hence they may affect its use. $D$ and $H$ are also included in the demand function because they may also affect the demand for CFs. TEC refers to the specific production technology, which decides the marginal productivity of a particular input, and thus affect the use of it. Note that $Q_{g}$ and $P_{g}$ do not appear in the input demand functions. This means that they do not affect the latter.

According to micro economic theory, the signs of $\partial x_{i} / \partial w_{i}(\mathrm{i}=1, \ldots, \mathrm{k})$ are negative and there is at least one input with positive $\partial x_{i} / \partial E P R I C E$, but we can not know what this particular input is (Sliberberg, 1990, pp. 160-166). As a result, we can not derive a prior exact sign of $\partial F E R T / \partial E P R I C E$ (FERT refers to the demand for CFs here).

We can not infer a prior signs of $\partial x_{i} / \partial w_{r}(\mathrm{i}=1, \ldots, \mathrm{k} ; \mathrm{r}=1, \ldots, \mathrm{k} ; \mathrm{i} \neq \mathrm{r})$ and $\partial x_{i} / \partial Z_{j}(\mathrm{i}=1, \ldots$, $\mathrm{k} ; \mathrm{j}=1, \ldots, \mathrm{l})$ either. Nevertheless, if $x_{r}$ is a substitute input for $x_{j}, \partial x_{i} / \partial w_{r}(\mathrm{i}=1, \ldots, \mathrm{k} ; \mathrm{r}=1, \ldots$, $\mathrm{k} ; \mathrm{i} \neq \mathrm{r}$ ) is expected to be positive; complement input, negative. Similarly if $Z_{j}$ is a substitute input for $x_{i}, \partial x_{i} / \partial Z_{j}$ is expected to be negative; complement input, positive.

Labor was argued to be a complement input for CFs by Griliches, but Metcalf and Cowling (1967, p379) disagreed to this argument with the reason that the use of CFs has not been found to decrease even if wage grows. Conversely that the secular rise in farm wages would raise the cost of self-supplied fertilizers such as farmyard manure and therefore lead to their replacement by commercial fertilizers has been argued by Hayami (1964). With the same reason, Huang and Rozelle (1996) attribute the growing use of CFs along with the decrease in self-supplied fertilizers to the increase in the opportunity cost of labor relative to CFs' price in China. According to this argument, the demand for CFs will increase as the wage of rural labor grows, the other things being equal. 
Unfortunately there are no data on wage of rural labor available to test this arguement. Nevertheless we can use the ratio of labor forces in cropping sector to cultivated land area as a proxy variable, which is expected to have negative coefficient in the demand function for CFs because the higher the ratio is, the lower the rural wage will be. I shall employ this proxy variable to test the argument that labor is a substitute for CFs in the next section's empirical study.

It is well known that CFs are substitutes for land, a quasi fixed input. Land reduction may increase land rents on the remaining area, thereby inducing increasing use of fertilizers on the remaining land. But there are no data on the price of agricultural land available in China either. Nevertheless we can employ proxy variable such as the ratio of cultivated land to population to reflect the relative scarcity of land. The lower this ratio is, the more expensive the land will be. Therefore, more fertilizers will be used to substitute for land.

Another fixed capital, agricultural machinery, is a substitute for labor, but it is neither a substitutable nor a complement input for CFs. So in the specific case of the use of CFs, the effect of fixed capital such as agricultural machinery can be neglected.

Operating inputs like pesticides and insecticides are supplements to CFs rather than substitutes (Hayami, 1964). But the quantity is rather small and their applications are later than that of CFs. The effect of their prices' change on the use of CFs can be considered to be negligible.

Disaster damages the current production and therefore reduce the the use of CFs during the current period. But it at the same time induces more CFs to be used in the subsequent production seasons to compensate for the loss. The net effect of disaster on the use of CFs depends on which effect is much stronger. Therefore disaster ratio can be used as an explanatory variable although we can not assume its sign in advance.

Because the adaptation of HRS has overcome the monitoring problem of the collective agriculture and linked farmers' income to their effects (Lin, 1988), this system has become one of the major engines of Chinese agricultural growth (Lin, 1992). This system may also cause more inputs including CFs to be used. $H$ in the demand function for CFs is then expected to have positive coefficient.

Technological progress raises the marginal productivity of CFs and thus induce much more CFs to be used, TEC is hence expected to have positive coefficient.

Concluding the above discussions, the demand function for CFs of Eq. (3) can be specified as

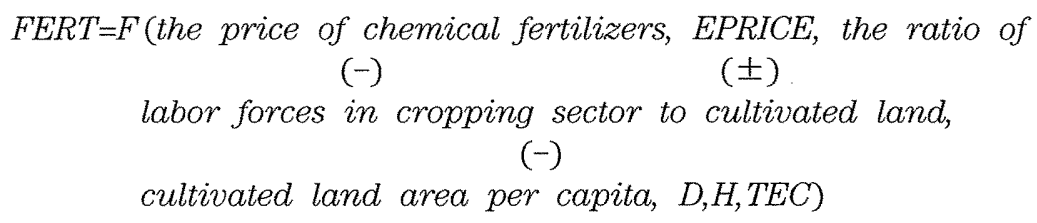

$$
(-) \quad( \pm)(+)(+)
$$

The theoretically expected signs of the respective parameters are shown in the parentheses under the variables. 


\section{EMPIRICAL STUDIES}

\section{1) The definition of variables}

\section{Dependent variables}

In this study, the index of the quantity of the "principal plant nutrients" of CFs with 1978 set to be the base year is used as the dependent variable (FERT).

Independent Variables

(1) Fertilizer price index, deflated by the general wholesale price index, with 1978 used as the base year (FERTP).

(2) Agricultural price index, deflated by the general wholesale price index, with 1978 used as the base year, serving as the expected price of agricultural products above government procurement quotas $(A G R P)^{4)}$.

(3) Labor forces in cropping sector per ha of cultivated land $(A L A B O R)$.

(4) Cultivated land area per capita ( $L A N D P$ ).

(5) The ratio of disaster stricken area to the totally sown area of crops, with the latter set to 100 (DISASTER). Disaster stricken area refers to the land where the yield is more than $30 \%$ lower than in the normal year caused by floods, droughts, and hail, etc..

(6) The ratio of production teams which have adopted HRS to the total production teams $(R H R S)$.

(7) Time trend variable with 1978 set to $0, \ldots, 1987$ to 19 (TIME), representing neutral technological progress.

\section{2) Data}

The data on FERT are shown in Table 1. The official data are used. In doing so, it should be noticed that no inventory of CFs or no year to year changes in the stock of CFs is assumed. FERT grew about 3.50 times over 1978-97. During the institutional reform period of $1978-84$, it almost doubled. While in the next 13 years, it grew 1.28 times.

The data on the explanatory variables are shown in Table 2. Due to the administrative control, FERTP remained relatively stable over the whole period, though it decreased during 1978-86, remained almost unchanged over 1987-94, and grew during 1994-97. On the other hand, $A G R P$ increased steadily during the sample period due to the price-raising policy. $A L A B O R$ and $\angle A N D P$ show decreasing tendency. Over the whole period, Chinese agriculture had been stricken by natural disaster though the degrees differed from $10.22 \%$ to $21.17 \%$. As introduced in Section 2, HRS appeared in 1979 and was established as the basic system in rural China by 1984 .

\section{3) Empirical Results}

Before the demand function is estimated, it is necessary to discuss the exogenous problem of CFs' price. Farmers are usually considered to be price-taker both in the product markets and in the input markets. Thus the individual farmers have no inpact on CFs' price. But when they behave together, their aggregate power may affect CFs' price significantly. Hence it becomes necessary to test whether the CFs' price is exogenously determined or not when aggregate data are used. Griliches (1958) and Lingard (1971) have taken this problem into consideration. Griliches (1958) argued that CFs are produced and sold by several major firms, with a price tag which is set by these firms in 
Table 2. Data on Explanatory Variables

\begin{tabular}{cccccccc}
\hline & $\begin{array}{c}\text { FERTP } \\
(\%)\end{array}$ & $\begin{array}{c}\text { AGRP } \\
(\%)\end{array}$ & $\begin{array}{c}\text { ALABOR } \\
\text { (Person/ha) }\end{array}$ & $\begin{array}{c}\text { LANDP } \\
\text { (Ha/person) }\end{array}$ & $\begin{array}{c}\text { DISASTER } \\
(\%)\end{array}$ & RHRS & TIME \\
\cline { 2 - 7 } Year & $(1)$ & $(2)$ & $(3)$ & $(4)$ & $(5)$ & $(6)$ & $(7)$ \\
\hline 1978 & 100.00 & 100.00 & 2.11 & 0.11 & 14.53 & 0.00 & 0 \\
1979 & 97.75 & 119.71 & 2.25 & 0.10 & 10.22 & 0.01 & 1 \\
1980 & 92.32 & 121.00 & 2.19 & 0.10 & 15.29 & 0.14 & 2 \\
1981 & 90.24 & 125.11 & 2.25 & 0.10 & 12.92 & 0.45 & 3 \\
1982 & 89.27 & 125.44 & 2.30 & 0.10 & 11.12 & 0.80 & 4 \\
1983 & 90.06 & 129.00 & 2.29 & 0.10 & 11.26 & 0.98 & 5 \\
1984 & 98.03 & 130.50 & 2.26 & 0.09 & 10.60 & 0.99 & 6 \\
1985 & 93.50 & 130.21 & 2.08 & 0.09 & 15.77 & 0.99 & 7 \\
1986 & 87.58 & 130.71 & 2.04 & 0.09 & 16.43 & 0.99 & 8 \\
1987 & 88.40 & 136.44 & 2.07 & 0.09 & 14.06 & 0.99 & 9 \\
1988 & 88.51 & 141.71 & 2.03 & 0.09 & 16.51 & 0.99 & 10 \\
1989 & 88.14 & 138.32 & 2.04 & 0.08 & 16.63 & 0.99 & 11 \\
1990 & 89.34 & 131.94 & 2.25 & 0.08 & 12.01 & 0.99 & 12 \\
1991 & 89.60 & 125.66 & 2.25 & 0.08 & 18.59 & 0.99 & 13 \\
1992 & 88.13 & 123.22 & 2.19 & 0.08 & 17.73 & 0.99 & 14 \\
1993 & 86.51 & 123.46 & 2.10 & 0.08 & 15.66 & 0.99 & 15 \\
1994 & 88.79 & 141.94 & 2.01 & 0.08 & 21.17 & 0.99 & 16 \\
1995 & 104.72 & 148.24 & 1.99 & 0.08 & 14.86 & 0.99 & 17 \\
1996 & 109.37 & 145.61 & 1.95 & 0.08 & 13.93 & 0.99 & 18 \\
1997 & 100.04 & 137.65 & 1.93 & 0.08 & 19.69 & 0.99 & 19 \\
\hline
\end{tabular}

Note: The definitions of variables are as follows:

FERTP: fertilizer price index, deflated by the general wholesale price index, with 1978 used as the base year; $A G R P$ : agricultural price index, deflated by the general wholesale price index, with 1978 used as the base year; $A L A B O R$ : labor forces in the cropping sector per ha of cultivated land area. Labor forces in the cropping sector were estimated from the data on agricultural labor forces. The latter includes those in cropping, animal husbandry, forestry, fishery, and sideline production. To obtain an estimate of the labor forces in cropping sector, the agricultural labor forces were weighted by the value of crop output in the total agricultural output, this method may involve bias; LANDP: cultivated land area per capita; DISASTER: the ratio of disaster stricken area to the total sown area of crops, with the latter being set to 100; HRS: the ratio of production teams which have adopted HRS to the total production teams.

Source: Fertilizer price index: CSY (1994, p. 329) for 1978-93, CSY (1998, p. 313) for 1994-97. The original data on chemical fertilizer prices were the indexes with the proceeding year set to 100 and I have adjusted it to set 1978 to 100 in order to keep consistency with other price index; The general wholesale price index and agricultural price index: CSY (1998, p. 315); The crops' value and agricultural value: Wen (1993, pp. 24-5, Table 7) for 1978-89, CSY (1998, p. 380) for 1990-97; Population: CSY (1990, p. 89) for 1978-83, CSY (1995, p. 59) for 1984-94, CSY (1998, p. 105) for 1995-97; Disaster stricken area: CSY (1984, p. 190) for 1978-83, CSY (1990, p. 389) for 1984-89, CSY (1998, p. 417) for 1990-97; Crops' sown area: Wen (1993, pp. 8-9, Table 2) for 1978-89, CSY (1998, p. 400) for 1990-97; The ratio of production teams which have adopted HRS to the total production teams: Lin (1992, p. 38, Table 3) for 1978-87. I simply extend the datum of 1987 until 1997 because HRS has not changed since then; Cultivated land area and agricultural labor forces: see Table 1. 
advance and does not vary too much within the crop season, and any disequilibrium expresses itself in seller's inventories. With the same reason, Lingard (1971) also treated the price as exogenous variable in his study of nitrogen demand in U.K.. As stated in Section 2.3 , in China, generally speaking, the government has strictly controlled the price of CFs. Consequently, the price of CFs can also be treated as determined exogenously.

The estimated results of the demand function are reported in Table 3. In Regression (1), $\ln A L A B O R$ and $\ln F E R T P$ do not get the expected signs and some of the t-values of the explanatory variables' parameters are rather small. I then explore the multicollinearity problem among the explanatory variables following the procedure introduced by Maddala (1977, pp. 183-190). The correlation coefficients between any two of the explanatory variables are calculated with the results shown in Table 4 . We can immediately find that $\ln L A N D P$ has very high correlation coefficients with the rest explanatory variables except with $\ln F E R T P$. $\ln A L A B O R$ also has correlation coefficients higher than 0.50 with the rest explanatory variables except with $\ln F E R T P$ and RHRS with only -0.344 and -0.311 respectively. However, it is still not enough to conclude that multicollinearity exists between $\ln L A N D P$ or $\ln A L A B O R$ and the rest explanatory variables from these results.

To make sure whether multicollinearity exists between $\ln L A N D P$ and the rest explanatory variables, I then calculate the following correlations (adjusted correlations) and partial correlations (adjusted partial correlations): $\mathrm{R}_{\text {ILLANDP }}^{2}$ (adjusted $\mathrm{R}_{\text {InLANDP }}^{2}$ ), $\mathrm{r}_{\text {InLANDP. }}^{2}$.

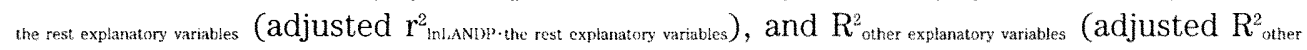

Table 3. Estimates of the Demand Function for CFs in China (dependent variable=InFERT)

\begin{tabular}{|c|c|c|c|c|c|c|}
\hline \multirow{5}{*}{$\begin{array}{l}\text { Explanatory } \\
\text { Variable }\end{array}$} & \multicolumn{6}{|c|}{ Method of estimation } \\
\hline & \multicolumn{2}{|c|}{ OLS } & \multicolumn{2}{|c|}{ OLS } & \multicolumn{2}{|c|}{$\mathrm{AR} 1(\mathrm{ML})$} \\
\hline & \multicolumn{6}{|c|}{ Regression number } \\
\hline & \multicolumn{2}{|c|}{ (1) } & \multicolumn{2}{|c|}{ (2) } & \multicolumn{2}{|c|}{ (3) } \\
\hline & Coef. & t-value & Coef. & t-value & Coef. & $t$-value \\
\hline CONSTANT & 0.137 & 0.14 & 0.772 & 1.38 & $2.059^{* * *}$ & 3.76 \\
\hline LnFERTP & 0.117 & 0.53 & -0.004 & -0.03 & $-0.284^{*}$ & -1.40 \\
\hline LnAGRP & $0.332^{s}$ & 1.57 & $0.459^{* * *}$ & 3.25 & $0.305^{*}$ & 1.75 \\
\hline LnALABOR & $0.783 * * *$ & 3.16 & $0.849 * * *$ & 3.69 & & \\
\hline LnLANDP & -0.698 & -0.82 & & & & \\
\hline LnDISASTER & 0.049 & 0.73 & 0.049 & 0.74 & -0.067 & -1.27 \\
\hline RHRS & $0.028^{s}$ & 1.58 & $0.027^{s}$ & 1.54 & 0.034 & 1.17 \\
\hline TIME & $0.025^{* * *}$ & 3.96 & $0.030 * * *$ & 26.11 & $0.030 * * *$ & 15.55 \\
\hline $\mathrm{R}^{2}$ & 0.997 & & 0.997 & & 0.991 & \\
\hline Adju. $R^{2}$ & 0.995 & & 0.995 & & 0.988 & \\
\hline D.W. & 1.91 & & 2.03 & & 1.76 & \\
\hline$\rho$ & & & & & $0.444^{*}$ & 1.85 \\
\hline
\end{tabular}

Note: OLS is the Ordinary Least Squares Procedure, and AR1(ML) is the First-order Autocorrelation Procedure estimated by Maximum Likelihood Procedure. ***: significant at the 1\% level; *: significant at the $10 \%$ level; : : significant at the $15 \%$ level; ": significant at the $20 \%$ level. $\rho$ is the estimate of the coefficient in the regression $e_{t}=\rho e_{t-1}+v_{t}$, where $e_{t}$ are the least squares residuals and $v_{t}$ are assumed to be serially independent. 
Table 4. Correlation Matrix of the Explanatory Variables

\begin{tabular}{lrrrrrrr}
\hline & InFERTP & InAGRP & InALABOR & InLANDP & InDISASTER & RHRS & TIME \\
\hline InFERTP & 1.000 & & & & & & \\
InAGRP & 0.104 & 1.000 & & & & & \\
InALABOR & -0.344 & -0.524 & 1.000 & & & & \\
LnLANDP & -0.030 & -0.750 & 0.574 & 1.000 & & & \\
LnDISASTER & -0.378 & 0.244 & -0.643 & -0.577 & 1.000 & & \\
RHRS & -0.218 & 0.726 & -0.311 & -0.785 & 0.323 & 1.000 & 1.000 \\
TIME & 0.148 & 0.689 & -0.627 & -0.985 & 0.594 & 0.725 & \\
\hline
\end{tabular}

Table 5. Testing Results of Multicollinearity between In LANDP or In ALABOR and the Rest Explanatory Variables

\begin{tabular}{|c|c|c|c|c|c|c|}
\hline \multirow{5}{*}{$\begin{array}{l}\text { Explanatory } \\
\text { variable }\end{array}$} & \multicolumn{2}{|c|}{ InFERT } & $\begin{array}{r}\text { Depende } \\
\text { FERT }\end{array}$ & $\begin{array}{l}\text { ariable } \\
\text { NDP } \\
\end{array}$ & \multicolumn{2}{|c|}{ InFERT } \\
\hline & \multicolumn{6}{|c|}{ Method of estimation } \\
\hline & \multicolumn{2}{|c|}{ AR1 (ML) } & \multicolumn{2}{|c|}{ OLS } & \multicolumn{2}{|c|}{ AR1 (CORC) } \\
\hline & (1 & & \multicolumn{2}{|c|}{$\begin{array}{l}\text { Regression number } \\
\text { (2) }\end{array}$} & \multicolumn{2}{|c|}{ (3) } \\
\hline & Coef. & $\mathrm{t}$-value & Coef. & t-value & Coef. & $t$-value \\
\hline Constant & $-1.745 * * *$ & -8.33 & -0.012 & -0.10 & $2.698^{* * *}$ & 34.40 \\
\hline InLANDP & $-3.919^{* * *}$ & -19.68 & -0.008 & -0.07 & & \\
\hline LnALABOR & & & & & 0.259 & 1.20 \\
\hline$R^{2}$ & 0.987 & & 0.033 & & 0.079 & \\
\hline Adju. $R^{2}$ & 0.986 & & -0.020 & & 0.024 & \\
\hline D.W. & 1.76 & & 1.77 & & 1.38 & \\
\hline$\rho$ & $0.665^{* * *}$ & 3.89 & $0.465 * *$ & 2.24 & $0.917 * * *$ & 10.01 \\
\hline
\end{tabular}

Note: FERTELANDP is the residual of InFERT after excluding what has been explained by the explanatory variables except $\ln L A N D P$ in Regression (1) of Table 3. AR1(CORC) is the First-order Autocorrelation Procedure estimated by Cochrane-Orcutt Procedure. ***: statistically significant at the $1 \%$ level; **: statistically significant at the $5 \%$ level.

explanatory variables). The results are shown in Regression (1) and (2) in Table 5 and Regression

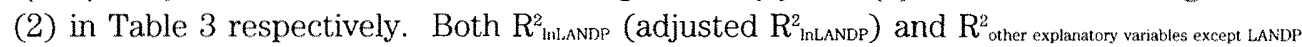

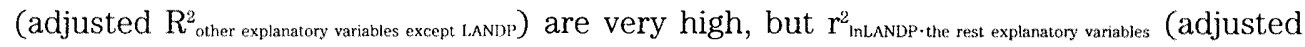
$\mathrm{r}_{\text {IILANDP the rest explanatory variables }}^{2}$ ) is very low. This means that after the effects of the explanatory variables other than $\ln L A N D P$ are excluded, $\ln L A N D P$ explains very little of the variation of $\ln F E R T$. Therefore, we can conclude that multicollinearity is serious between $\ln L A N D P$ and the rest explanatory variables.

The same test is done with respect to $\ln A L A B O R$ and the result is Regression (3) in Table 5. $\mathrm{R}_{\text {InALABOR }}^{2}$ (adjusted $\mathrm{R}_{\mathrm{IALABOR}}^{2}$ ) is very low. Thus we can not conclude that multicollinearity between $\ln A L A B O R$ and the rest explanatory variables is also a serious problem. So after dropping out $\ln L A N D P$, the demand function is estimated again and 
the result is Regression (2) in Table 3 . Some estimates including $\ln F E R T P$ are still not statistically significant. Worst of all, the parameter of $\ln A L A B O R$ still gets statistically significantly positive sign in contrast to the theoretical expectation. Basing on these results, the argument that labor is a substitute for CFs can be rejected at least during the sample period. The result is also consistent with our observations on contemporary rural China. On the one hand, there are numerous surplus agricultural labor forces (Cook, 1999) both yearly and seasonally in rural China. On the other hand, contrary to CFs, self-supplied fertilizers are usually put into field during slack farming season. All of these mean that the opportunity costs of labor for preparing and using self-supplied fertilizers in rural China are near to zero.

Because it is hard to argue that labor is a complement input for CFs, especially when the number of labor per ha of cultivated land area rather than the number of work days per ha of cultivated land area is used to represent the labor, $\ln A L A B O R$ has to be omitted in estimating the demand function for CFs.

The estimated results of the demand function without $\ln A L A B O R$ and $\ln L A N D P$ are Regressions (3) in Table 3 . All of the parameters of the variables get the theoretically expected signs. The estimates of $\ln F E R T P, \ln A G R P$, and TIME are statistically significant at least at the $20 \%$ level. The absolute t-values of the parameters of the rest two explanatory variables, $\ln D I S A S T E R$ and $R H R S$, are larger than 1 and in fact statistically significant at the $25 \%$ level. The following analysis will be based on this Regression. We get the demand elasticities for CFs with respect to its own price and agricultural price with -0.284 and 0.305 respectively, but caution should be taken when comparing these results with other estimates. The positive parameter of TIME strongly suggests that the demand for CFs in Chinese agriculture has increased through technological progress.

\section{ACCOUNTING FOR THE USAGE GROWTH OF CFS}

Writing down the demand function in Regression (3) in table 3 in detail, we can get

$$
\begin{aligned}
\ln \left(\frac{F E R T_{(1978+T M E)}}{F E R T_{1978}} \times 100\right) & =2.059-0.284 \ln \left(\frac{F E R T P_{(1978+7 M E)}}{F E R T P_{1978}} \times 100\right) \\
& +0.305 \ln \left(\frac{A G R P_{(1978+7 T M E)}}{A G R P_{1978}} \times 100\right)-0.067 \ln D I S A S T E R_{(1978+T M M t)} \\
& +0.034 R H R S+0.030 T I M E+\varepsilon
\end{aligned}
$$

Using variable transformation

$$
1978+\text { TIME }=t_{0}+\text { time, }
$$

here $t_{0}$ refers any fixed base year, and differentiating Eq. (5) with respect to time, the following equation can be obtained.

$$
\begin{aligned}
g\left(\text { FERT }_{(t o+t i m e)}\right)= & -0.284 g\left(\text { FERTP }_{(t o+t \text { time })}\right)+0.305 g\left(\text { AGRP }_{(t o+t \text { time })}\right) \\
& -0.067 g\left(D I S A S T E R_{(t i+t i m e)}\right)+0.034 \frac{\partial R H R S}{\partial t i m e}+0.030+\frac{\partial \varepsilon}{\partial t i m e}
\end{aligned}
$$


Here

$$
\begin{aligned}
& g\left(F E R T_{(t 0+\text { time })}\right)=\frac{1}{F E R T_{(i 0+\text { time })}} \frac{\partial F E R T_{(t 0+\text { time })}}{\partial \text { time }}, \\
& g\left(\operatorname{FERTP}_{(t 0+t i m e)}\right)=\frac{1}{\operatorname{FERTP}_{(10+t i m e)}} \frac{\partial \operatorname{FERTP}_{(10+\text { time })}}{\partial \text { time }}, \\
& g\left(A G R P_{(t 0+\text { time })}\right)=\frac{1}{A G R P_{(0+\text { time })}} \frac{\partial A G R P_{(t 0)+\text { time })}}{\partial t i m e}, \\
& g\left(D I S A S T E R_{\left(10+\text { time }_{i}\right)}\right)=\frac{1}{D I S A S T E R_{(00+\text { time })}} \frac{\partial D I S A S T E R_{(t 0+\text { time })}}{\partial t_{0}+\text { time }}
\end{aligned}
$$

i.e. they are the growth rate of the respect variables. Assuming these variables grow with constant rate annually, the following relationship is held.

$$
X_{(0+\text { time })}=X_{t 0}\left(1+g\left(X_{(10+\text { time })}\right)\right)^{\text {sime }}
$$

Here $X_{(t 0+t i m e)}$ refers to the four variables above. $g\left(X_{(t 0+t i m e)}\right)$ during two subperiods,

\begin{tabular}{|c|c|c|c|c|c|}
\hline \multirow{3}{*}{$\begin{array}{l}\text { Explanatory } \\
\text { Variable }\end{array}$} & \multicolumn{2}{|c|}{$1978-84$} & \multicolumn{3}{|c|}{ 1984-97 } \\
\hline & $\begin{array}{c}\text { Estimated } \\
\text { coef. }\end{array}$ & $\begin{array}{c}\text { Growth rate in } \\
\text { variable }\end{array}$ & Contribution & $\begin{array}{l}\text { Growth rate in } \\
\text { variable }\end{array}$ & Contribution \\
\hline & (1) & (2) & $(3)=(1) *(2)$ & (4) & $(5)=(1) *(4)$ \\
\hline FERTP & -0.284 & -0.331 & $\begin{array}{c}0.094 \\
(0.79)\end{array}$ & 0.156 & $\begin{array}{l}-0.044 \\
(-0.68)\end{array}$ \\
\hline LnAGRP & 0.305 & 4.537 & $\begin{array}{r}1.384 \\
(11.58)\end{array}$ & 0.428 & $\begin{array}{r}0.131 \\
(1.99)\end{array}$ \\
\hline DISASTER & -0.067 & -5.120 & $\begin{array}{c}0.343 \\
(2.87)\end{array}$ & 4.879 & $\begin{array}{l}-0.327 \\
(-4.97)\end{array}$ \\
\hline RHRS & 3.400 & 0.165 & $\begin{array}{c}0.561 \\
(4.70)\end{array}$ & 0.000 & $\begin{array}{r}0.000 \\
(0.00)\end{array}$ \\
\hline TIME & 3.000 & 1.000 & $\begin{array}{r}3.000 \\
(25.11)\end{array}$ & 1.000 & $\begin{array}{r}3.000 \\
(45.64)\end{array}$ \\
\hline Residual & & & $\begin{array}{c}6.57 \\
(54.96)\end{array}$ & & $\begin{array}{c}3.81 \\
(58.02)\end{array}$ \\
\hline FERT & & 11.95 & $\begin{array}{c}11.95 \\
(100.00)\end{array}$ & 6.57 & $\begin{array}{c}6.57 \\
(100.00)\end{array}$ \\
\hline
\end{tabular}
1978-84 and 1984-97 ( $t_{0}$ is 1978 and 1984 respectively), can be easily calculated on the basis of Eq. (7) from Table 1 and 2 and the results are shown in Table 6.

In Eq. (6), the first two terms on the right-hand side measure the effect of CFs' price

Table 6. Accounting for the Growth Rate of CFs

Note: In Eq. (6), therefore in this Table, the variables except RHRS and TIME are in percentage. To calculate the contribution of these two variables to the growth rate of CFs, the estimated coefficients have been multiplied by 100 . For these two variables, the growth rate refers to the average yearly change in magnitude of these variables between the first and final years. The figures in parentheses are the percentage shares of contribution to yearly average growth rate of CFs with the latter set to 100. 
and agricultural price on the growth of CFs respectively. The third term captures the impact of disaster. The fourth term reflects the effect of HRS. The fifth term is the effect of neutral technological progress. The last term captures the time-varying influences on the growth of CFs not already accounted for, which is mainly the result of unneutral technical progress including improvements in the usage technologies of peasants.

The growth accounting for CFs during two sub-periods, 1978-84 and 1984-97, can be carried out on the basis of Eq. (6) and the results are reported in Table 6. CFs grew at an annual average rate of $11.95 \%$ over the 1978 to 1984 period. From the accounting in Table 6 , it appears that $25.11 \%$ of this growth came from neutral technological progress, which was the most important source during this period. Agricultural price growth contributed to $11.58 \%$. The shift from the production team to HRS also contributed to $4.70 \%$. The contributions of disaster and CFs' price growth were very limited with $2.87 \%$ and $0.79 \%$ respectively. In the growth rate accounting, $54.96 \%$ was unexplained residual.

Over 1984-97, the annual average growth rate of CFs was $6.57 \% .45 .64 \%$ of this growth came from neutral technological progress, which was still the most important source. Agricultural price growth also contributed to $1.99 \%$. Disaster and CFs' price growth caused CFs to decrease $4.97 \%$ and $0.98 \%$ respectively. In this sub-period, the effect of HRS vanished. In the growth accounting, $58.02 \%$ was unexplained residual.

In both sub-periods, the large unexplained residuals may attribute to unneutral technological progress.

\section{CONCLUDING REMARKS}

Similar to what have been made clear in other countries by previous studies, the demand for CFs in China is affected by its own price negatively and agricultural price positively, though the magnitudes of the former were negligible in both sub-periods. Technological progress contributed to the CFs' growth greatly. The adoption of HRS contributed to $\mathrm{CF}$ growth rate during the institutional reform period. Disaster also affected the use of CFs negatively. The argument that labor is a substitute for CFs could not have been verified empirically in this study.

The implication of the study is that we can control CF applications either by lowering the agricultural price or raising CFs' price or both. It seems not to be appropriate to restrict the use of CFs by controlling agricultural price because it may result in agricultural depression as the cost of agricultural labor, etc, will surely grow. The most feasible measure to control the use of CFs seems to raise their prices or put a tax on them.

One deficiency of this study is that though cultivated area per capita representing the scarcity of agricultural land explained quite a lot the variation of the demand for CFs alone, its effect could not have been separated from that of other variables because of multicollinearity. Consequently this variable has to be omitted in empirical estimation of the demand function for CFs.

NOTE

1) Though village is an autonomous community rather than a level of local government 
according to the Constitution, the town and village public welfare and development expenses must be fulfilled. Therefore, I simply refer both the government procurement quotas and the town and village public welfare expenses to government procurement quotas here. The household consumption requirements for agricultural products are usually met by their own production. But the subsistence products should also be valued on the basis of the expected price of agricultural products above government procurement quotas at the time of CFs' applications because if a household did not produce them itself, it had to buy them in this price.

2) Though this specification is with regard to the agricultural household under HRS, it apparently also applies to the behavior of the production team under the People's Commune System.

3) China is a geographically large country almost stricken by disaster every year though the degrees of damages are different from year to year and region to region. Disaster has affected Chinese agricultural production significantly (Kueh, 1986).

4) CFs are mainly used in crops' production though they may also be used as fish feed and for feed production, etc.. Therefore, there are some biases in the estimated results employing agricultural price rather than crops' price. Though farmers are allowed to sell agricultural products after fulfilling government procurement quotas in free markets, if the market prices fall below the government protection price, they can sell all the products to the state-owned enterprises they are willing to with the protection prices. This means that farmers can plan their production at least on the basis of the protection prices. Hence the current year agricultural price can simply be used as the expected price. In this study, the price index data in CSY are used. As pointed out in Section 4, the expected price should be beyond the price of government procurement quotas, while the price index in CSY is just the average price of government procurement quotas and above government procurement quotas, so there may be some biases when employing the price index data in CSY.

\section{REFERENCES}

Boyle, G. "Modeling Fertilizer demand in the Republic of Ireland: A Cost Function Approach," Journal of Agricultural Economics, Vol. 33, 1982, pp. 179-192.

Burrell. A. "The Demand for Fertilizer in the United Kingdom," Joumal of Agricultural Economics, Vol. 40, 1989, pp. 1-56.

Cheng, Z. The Fifty Years of Chinese Price (in Chinese: Zhongguo Wujia Wushi Nian), Beijing: China Price Press, 1998.

Cook, S. "Surplus Labor and Productivity in Chinese Agriculture: Evidence from Household Survey Data," Joumal of Development Studies, Vol. 35, 1999, pp. 16-44.

Du, W. Agricultural Marketed Surplus Response in China, Gateshead, Tyne and Wear: Athenacum Press, 1995.

Griliches, Z. "The Demand for Fertilizer: An Economic Interpretation of a Technical Change," Joumal of Farm Economics, Vol. 40, 1958, pp. 591-606.

Hayami, Y. "Demand for Fertilizer in the Course of Japanese Agricultural Development," American Journal of Agricultural Economics, Vol. 46, 1964, pp. 766-779.

Hayami, Y. and V. Ruttan. "Agricultural Development: an International Perspective," London: The John Hophins University Press, 1985. 
Heady, E. O., and M. Yeh. "National and Regional Demand functions for Fertilizer," Journal of farm Economics, Vol. 41, 1959, pp. 332-348.

Huang J., and S. Rozelle. "Environment stress and Grain Yields in China," American Journal of Agricultural Economics, Vol. 77, 1995, pp. 853-864.

Huang J., and S. Rozelle. "Technological Change: Rediscovering the Engine of Productivity Growth in China's Rural Economy," Joumal of Development Economics, Vol. 49, 1996, pp. 337-369.

Kueh, Y. Y. "Weather Cycles and Agricultural Instability in China," Joumal of Agricultural Economics, Vol. 37, 1986, pp. 101-104.

Larson, B. A., and H. Vroomen. "Nitrogen, Phosphorus and Land demands at the U.S. Regional level: A Primal Approach," Jourmal of Agricultural Economics, Vol. 42, 1991, pp. 354-364.

Lin, J. Y. "The Household Responsibility System in China's Agricultural Reform: A Theoretical and Empirical Study," Economic Development and Cultural Change, Vol. 36, 1988, pp. S199-S244.

Lin, J. Y. "Rural Reforms and Agricultural Growth in China," The American Economic Review, Vol. 82, 1992, pp. 34-51.

Lingard, J. "Aggregate Demand for Nitrogenous Fertilizer in the United Kingdom: Another Look," Journal of Agricultural Economics, Vol. 22, 1971, pp. 179-193.

Maddala, G. S. Econometrics, McGraw-Hill Kogakusha, 1977.

Metcal, D., and K.Cowling, "Demand Function for Fertilizer in the United Kingdom," Journal of Agricultural Economics, Vol. 18, 1967, pp. 375-386.

Sliberberg, E. The Structure of Economics: A Mathematical Analysis, Second Edition, McGraw-Hill, INC., 1990.

Wen, G. J. "Total Factor Productivity Change in China's Farming Sector: 1952-1989," Economic Development and Cultural Change, Vol. 141, 1993, pp. 1-41.

Yao, S., and Z. Liu. "Determinants of Grain Production and Technical Efficiency in China," Journal of Agricultural Economics, Vol. 49, 1998, pp. 171-184.

Ye, Q., and, S. Rozelle. "Fertilizer Demand in China's Reforming Economy," Canadian Joumal of Agricultural Economics, Vol. 42, 1994, pp. 191-207.

Zhang, B., and C. A. Carter, "Reforms, the Weather, and Productivity Growth in China's Grain Sector," American Journal of Agricultural Economics, Vol. 79, 1997, pp. 1266-1277. 